\title{
THE ELECTROPHORETIC ANALYSIS OF MATERNAL AND FETAL PLASMAS AND SERA
}

\author{
By LEWIS G. LONGSWORTH, RAYMOND M. CURTIS, \\ AND RICHARD H. PEMBROKE, JR. \\ (From the Laboratories of The Rockefeller Institute for Medical Research, New York, \\ and the Union Memorial Hospital, Baltimore)
}

(Received for publication May 24, 1944)

\section{INTRODUCTION}

The fact that the concentrations of the serum proteins in fetal, maternal, and normal blood are different has been known for some time. The results of recent investigations (1 to 3 ) are summarized in Table $I$. Although the values

TABLE I

Comparison of the results of previous investigators for the serum protein content of fetal, maternal, and normal blood

(Concentrations expressed as grams of protein per 100 ml. of serum, or plasma. Globulin precipitated with salt solution)

\begin{tabular}{l|c|c|c|c|c|c}
\hline \hline & $P_{S}$ & $P_{A} / P_{G}$ & $P_{S}$ & $P_{A} / P_{G}$ & $P_{S}$ & $P_{A} / P_{G}$ \\
\hline Normal adult & 7.11 & 1.64 & & & 6.73 & 2.32 \\
Fetal & 5.91 & 1.66 & 5.11 & 2.80 & 5.45 & 2.28 \\
Maternal & 6.75 & 1.49 & 7.20 & 2.20 & & \\
\hline Reference & $(1)^{*}$ & \multicolumn{2}{|c|}{$(2) \dagger$} & (3) $\ddagger$ \\
\hline
\end{tabular}

* Average values of 15 samples each of normal, maternal, and cord blood.

† Average values of 17 samples of fetal blood and 6 samples of blood from mothers of premature children.

† Average values of 33 samples of normal blood and 74 samples from infants 0 to 7 days old.

obtained by different workers for a given type of material are not in quantitative agreement, the results of any one research are consistent in indicating certain systematic differences between bloods from the three sources. Thus, the concentration, $P_{S}$, of serum protein in fetal blood is lower than in that of normal adults. The ratio, $P_{A} / P_{G}$, of albumin to globulin is, on the other hand, not very different in the two cases. Finally, maternal bloods, taken during the later stages of pregnancy or at term, tend to have a concentration of total serum protein that is not very different from the normal values but in which the albumin-globulin ratio is low.

In obtaining these results, the solubility of albumin, globulin, and fibrinogen in aqueous salt solutions was used for the separation of these plasma fractions. This method does not distinguish. between the antibody globulins and the immunologically inactive globulins. In view of the evidence (4) as to the considerable immunity possessed by the new-born infant, it appeared that it would be of interest to obtain this additional information. Electrophoresis by the Tiselius procedure (5) affords a new and effective method for the analysis of serum or plasma and permits the separation of plasma globulin into at least four electrophoretically distinguishable components exclusive of fibrinogen (6). While there is no reason to think that the $\gamma$ globulin of Tiselius consists wholly of immune bodies, there is much evidence (7) that these bodies are $\gamma$ globulins. It is the purpose of this paper to report the results of the electrophoretic analyses of ten pairs of plasmas, or sera, taken from the placenta and the mother at the time of child birth and to compare the values thus obtained with each other and with those for normal adults (8).

\section{EXPERIMENTAL}

As described elsewhere (9), uncontaminated fetal blood was drawn from the cord immediately after the birth of the child, prior to the expulsion of the placenta. Blood from a vein in the anticubital fossa of the mother was taken, with a minimum of stasis, about one hour after delivery. We have not studied the changes in the plasma due to loss of blood on delivery or to the anesthesia. These changes probably cause slight alterations in the concentration of total plasma protein but not in the relative proportions of the different components.

In the case of plasma, $10 \mathrm{ml}$. of 2.5 per cent sodium citrate in physiological saline was used as anticoagulant for each $100 \mathrm{ml}$. of blood. The plasma, or serum, was separated, shipped frozen in dry ice from Baltimore to New York, and stored at $0^{\circ} \mathrm{C}$. until analyzed. During storage, a small amount of precipitate, presumably a fibrin clot, formed in the plasma samples, and was removed by centrifugation prior to electrophoresis. The electro- 
phoresis procedure has, for the most part, been adequately described elsewhere (6). The following routine details of manipulation have not, however, hitherto been published.

A buffer solution, $0.1 \mathrm{~N}$ in sodium diethyl barbiturate and $0.02 \mathrm{~N}$ in the free acid, has been shown to be a satisfactory solvent for the electrophoretic analysis of the human plasma proteins and was used exclusively throughout this research. Two liters of this buffer were prepared for each analysis by adding $\mathbf{4 4 . 1 8}$ grains of U.S.P. "Barbital," $100 \mathrm{ml}$. of carbonate-free $2 \mathrm{~N}$ sodium hydroxide, and $1500 \mathrm{ml}$. of water to a 2 liter volumetric flask, heating until the acid was dissolved, cooling to $20^{\circ}$, and filling to the mark with water. This buffer solution has a $\mathrm{pH}$ of 8.64 at $20^{\circ}$ and 8.78 at $10^{\circ}$, a value of 4.00 being taken as the $\mathrm{pH}$ of 0.05 molar potassium acid phthalate at both temperatures. The specific conductance at $0^{\circ}$ is 0.00302 mhos. and the refractive index increment, also at $0^{\circ}$ and for a wavelength, $\lambda$, of $5780 \AA$., is 0.00460 . Eight ml. of this solution were added to $7 \mathrm{ml}$. of citrated plasma, or $9 \mathrm{ml}$. to $6 \mathrm{ml}$. of serum, in a bag made of $3 / 4$ " Visking tubing and the latter tied and suspended in $250 \mathrm{ml}$. of the buffer solution in a footed cylinder. After dialysis at $\mathbf{0}$ to $3^{\circ}$ for one day, the buffer solution in the cylinder was replaced and the dialysis continued for a second day. The bag and contents were then transferred to the remaining 1.5 liters of buffer solution for dialysis for a third day, this solution being subsequently used as supernatant in forming the boundaries and for filling the electrode vessels.

Some of the maternal samples contained fat in suspension which interfered with the schlieren photography. The suspended fat globules scatter the light and thus lead to under-exposure of the portion of the pattern conjugate to that part of the cell in which the globules are present. This is the region below the $\beta$-globulin peak in each side of the channel since in this case the particles were found to have the same mobility in the electric field as this plasma component. If one attempts to compensate for this scattering simply by increasing the exposure, the remaining portion of the pattern is then over-exposed. In order to overcome this difficulty, either the plasma must be clarified prior to electrolysis or photographic compensation, other than increased exposure, must be achieved. Clarification by extraction with fat solvents is not advisable because of the resulting modification of the lipo-proteins in clear solution in plasma. Centrifugation in an angle centrifuge at 30,000 r.p.m. for 30 minutes is completely effective, causing the suspended fat to rise as a cream without appreciable sedimentation of the plasma proteins. As a routine procedure, however, for the separation of traces of sediment, all of our samples are centrifuged at 5000 r.p.m. and $0^{\circ}$, using flattened tubes of $6 \mathrm{ml}$. capacity. This is partially effective in clarifying a plasma, or serum, that is opalescent due to suspended fat and is usually sufficient if supplemented by photographic compensation. Thus the red light obtained from a tungsten filament and the Wratten A filter is scattered less than the yellow light given by the $\mathrm{H} 4$ mercury lamp and the $\mathrm{E}$ filter. This observation confirms that of others (10) who suggested the use of infra-red light. We have also noted that a photographic plate having less contrast than the Wratten C.T.C. plates usually employed, such as a Wratten panchromatic plate, reduces the effect of the scattering without materially decreasing the sharpness with which the pattern is defined.

\section{RESULTS}

The patterns of a maternal plasma and the corresponding fetal plasma are shown in Figures 1 and 2 , respectively. These patterns were obtained from that side of the U-shaped electrophoresis channel in which the boundaries were rising. The patterns- of both the rising and descending boundaries, obtained during the electrolysis of maternal plasma 1 of this paper, have already been published, Figure 6 of Reference 6 , in connection with a study of the effect of the buffer solution upon the analysis of human material. In the present research, both patterns have been used in the analyses, as will now be described.

Tracings of the patterns, enlarged 2.5 diameters, are made and the area due to a component $i$, as defined by Tiselius and Kabat (7), determined with the aid of a planimeter. This area is designated as $A_{\text {id }}$ if the boundary is descending, $A_{i r}$ if it is rising. The total area, $A_{t}$, of the pattern from one side of the channel should be the same as that from the other side since this area is proportional to the integral, $\int_{n_{B}}^{n_{P}}(d n / d h) d h$, whose limits, the refractive indices of the protein solution, $n_{P}$, and the buffer solution, $n_{B}$, are the same for both channels. The relation is

$$
\begin{aligned}
& \int_{n_{B}}^{n_{P}}(d n / d h) d h=n_{P}-n_{B}=A_{t} / a b G E_{c} E_{t} \pi \\
& \text { in which } h=\text { height in the channel } \\
& a=\text { cell thickness }=2.50 \mathrm{~cm} . \\
& b=\text { optical distance from cell to schlie- } \\
& \text { ren diaphragm }=183 \mathrm{~cm} \text {. } \\
& \begin{array}{c}
G=\text { ratio of plate to diaphragm travel } \\
=3.00
\end{array}
\end{aligned}
$$

1 If the wavelength of the light is varied during a series of analyses, correction should be made for the effect of this variation upon the specific refractions of the plasma proteins. With the aid of the schlieren scanning camera, a $60^{\circ}$ hollow prism cell (11), and a G.E. special spectrum mercury-cadmium lamp of the $\mathrm{H} 4$ type, we have measured the dispersion of plasma in the diethyl barbiturate buffer at $0^{\circ} \mathrm{C}$. If the specific refractive increment, $k$, is taken as 0.00186 for $\lambda=5780$, then $k_{4360}=0.00196, k_{\text {soss }}$ $=0.00190, k_{\mathrm{s} 60}=0.00187$, and $k_{6438}=0.00183$. 


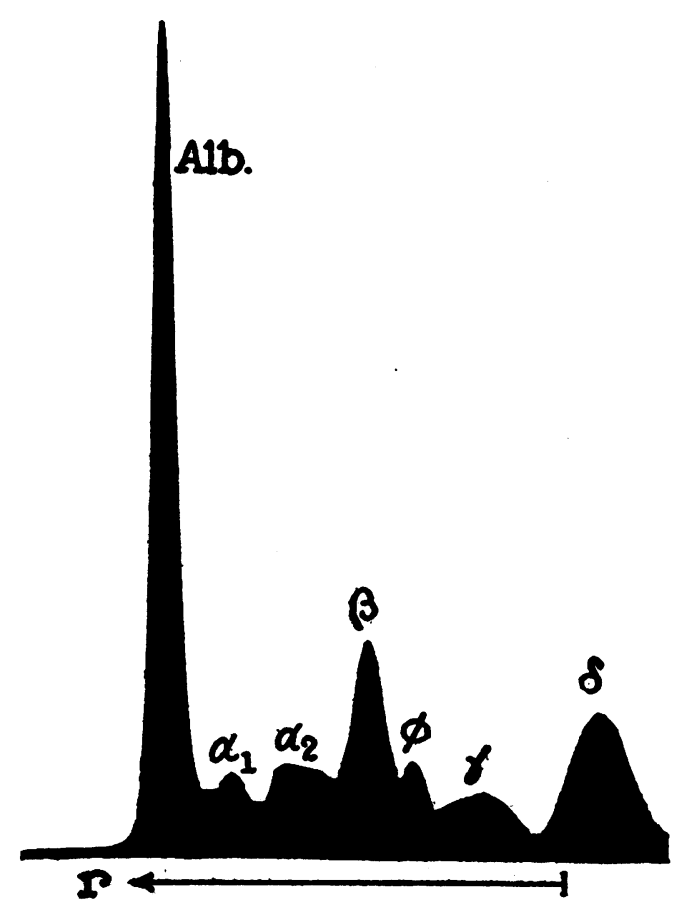

Fig. 1. Electrophoretic Pattern of Maternal Plasma Number 5, Diluted 1:2.55, after Electrolysis FOR 14,000 SECONDS AT 5.35 VOLTS PER CM.

$$
\begin{aligned}
& E_{c}=\text { camera enlargement }=\frac{1.00}{2.50^{2}} \\
& E_{t}=\text { tracing enlargement }=6.25 \\
& \quad=0.52
\end{aligned}
$$

The corresponding protein concentration, $p$, is

$$
p=\left(n_{P}-n_{B}\right) / k
$$

in which $k$ is the specific refraction increment. If $D$ is the factor by which the plasma, or serum, was diluted prior to electrophoresis the original concentration, $P$, in grams of protein per $100 \mathrm{ml}$. of solution is

$$
P=D P
$$

Except for small uncertainties in $D, A$, and $k$, the quantities entering into equations 1,2 , and 3 are known with ample precision. One uncertainty in the dilution factor, $D$, is due to the entrance, during dialysis, of a small amount of water into the bag containing the protein solution. In one experiment, in which this effect was measured, the bag increased 2.6 per cent in volume during the 3 -day period of dialysis. A comparison of the refractive index difference,

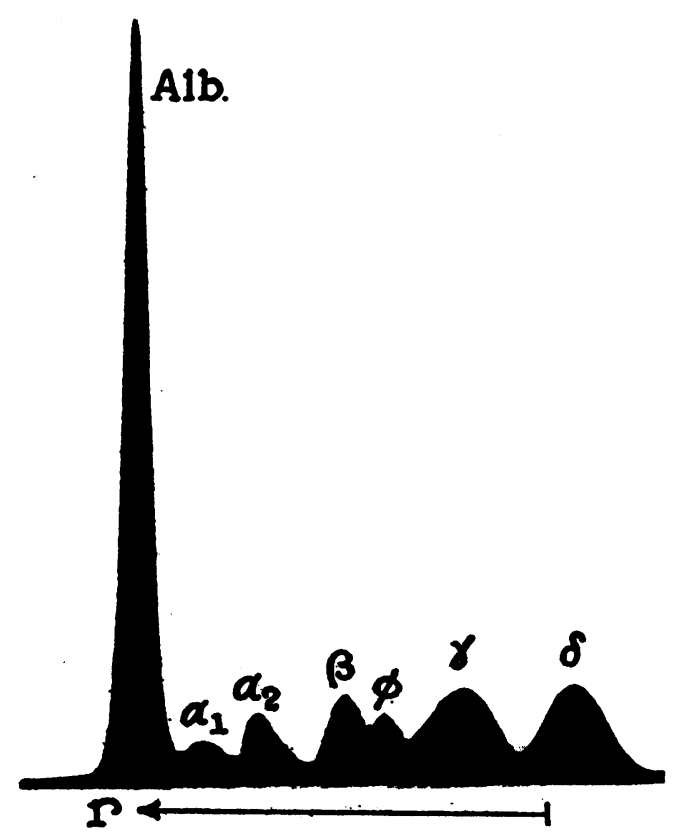

Fig. 2. Electrophoretic Pattern of Fetal Plasma Number 5, Diluted 1:2.78, AFter Electrolysis for 14,000 SECONDS AT 5.33 VOLTS PER CM.

$n_{P}-n_{B}$, computed from equation 1 with that measured directly, using the $60^{\circ}$ hollow prism cell (11), indicates, however, that the values of the total pattern area are subject to a systematic personal error in the tracing procedure that compensates for the dilution error just noted.

In the case of plasma, another uncertainty in $D$ arises from the diluting effect of the solution used as anticoagulant. If the average volume of red cells in the maternal bloods, for example, is 36.3 per cent (12), the plasma is thereby diluted by a factor of $(63.7+10) / 63.7$ since 10 $\mathrm{ml}$. of anticoagulant were used for each $100 \mathrm{ml}$. of blood. Moreover, the citrate solution is hypertonic and causes a contraction of the red cells, the accompanying transfer of water from the red cells to the plasma causing an additional dilution of the latter. If sodium and potassium citrates are assumed to have the same molar tonicity, interpolation from the data of Heller and Paul (13) yields a red cell shrinkage of 6.1 per cent in the case of our anticoagulant. The total dilution of the plasma separated from the blood is, therefore, $(63.7+10+36.3 \times 0.061) /$ 
TABLE II

Comparison of the concentrations of total protein in plasmas and sera from determinations of protein nitrogen, pattern areas, and dry weight

\begin{tabular}{l|c|c|c}
\hline \hline \multicolumn{1}{c|}{ Sample } & Protein N & Pattern area & Dry wt. \\
\hline Maternal 7 & 6.63 & 7.24 & \\
Fetal 7 & 6.07 & 6.28 & \\
Maternal I & 6.75 & 7.83 & \\
Fetal II & 6.57 & 6.90 & \\
Fetal IV & 5.88 & 6.27 & 6.24 \\
Maternal V & & 8.00 & $\mathbf{8 . 0 2}$ \\
\hline
\end{tabular}

$63.7=1.192$. The corresponding factor for fetal plasma is $(47.2+10+52.8 \times 0.078) / 47.2$ $=1.299$.

The specific refraction, $k$, is defined by equation 2. In addition to its dependence on the temperature, the wavelength, and the type of protein, $k$ also varies with the nature of the buffer electrolytes due to the unequal distribution of the buffer ions between the two solutions when the latter are in a Donnan equilibrium (14). Moreover, owing to the presence of nitrogen-free constituents, such as lipids and carbohydrates, in many of the plasma proteins, a dry-weight determination of $p$, equation 2 , yields a smaller value for $k$ than a determination of protein nitrogen if the latter is multiplied by the conventional factor of 6.25 . In this research, we have assumed the specific refractions of all of the plasma proteins to be the same and equal to 0.00186 at $0^{\circ}$ and for $\lambda=5780$. From a consideration of the additivity of atomic refractions, it is probable that the specific refraction of a lipid- or carbohydrate-containing protein is but slightly less, on a dry-weight basis, than one for which the nitrogen factor is 6.25 . The data of Table II indicate, in agreement with the foregoing conclusions, that our values for the protein concentrations are somewhat higher than those obtained in the usual manner from nitrogen determinations, being more nearly comparable with measurements of dry weight.

Finally, in order to compute the concentrations, $P_{i}$, of the individual components, correction must be made for the $\epsilon$ and $\delta$ effects. These effects, it will be recalled, are due to gradients of buffer salt and buffer salt plus protein, respectively, and do not represent plasma components. The relative concentration of the $i$-th component is given very closely by $A_{i d} /\left(A_{t}-A_{\epsilon}\right)$ for a descending boundary and by $A_{i r} /\left(A_{t}-A_{\delta}\right)$ for a rising boundary, the $A$ 's denoting pattern areas as defined earlier in this paper. The relative values are not subject to many of the uncertainties that enter into the determination of the absolute protein concentrations.

The preceding methods of computation are illustrated by the data of Table III for fetal plasma 7. The areas from the patterns of the descending and rising boundaries are recorded in lines 1 and 2, respectively. The average total area, 608, yields 6.42 per cent as the total plasma protein concentration, $P_{P}$, on substitution in equations 1 to 3 . The relative concentrations from the two patterns are recorded in lines 3 and 4 of Table III and their average values in line 5. Multiplication of these relative values by $P_{P}$ gives the concentrations of the individual components, line 6 . The relative concentrations on a serum basis are given in the last line of the table, $P_{S}$ indicating the total serum protein concentration, i.e., $P_{P}-P_{\phi}$.

The results for the maternal samples are summarized in Table IV, plasmas and sera being identified by arabic and roman numerals, respectively. The fetal member of a pair is then indicated by the same number in Table V. Both the actual and the relative concentrations of each component are reported, the latter on a serum basis, i.e., $P_{i} / P_{S}$, except in the case of

TABLE III

Electrophoretic analysis of fetal plasma No. 7

\begin{tabular}{|c|c|c|c|c|c|c|c|c|c|c|}
\hline & Component & Albumin & $\mathbf{a r}$ & $\infty$ & $\boldsymbol{\beta}$ & $\phi$ & $\boldsymbol{\gamma}$ & $\delta$ & - & Total \\
\hline $\begin{array}{l}1 \\
2 \\
3 \\
4 \\
5 \\
6 \\
7\end{array}$ & $\begin{array}{l}A_{i d} \\
A_{i r} \\
A_{i d} /\left(A_{t}-A_{t}\right) \\
A_{i r} /\left(A_{t}-A_{\delta}\right) \\
\text { Mean }=P_{i} / P_{P} \\
P_{i}(\mathrm{~g} / 100 \mathrm{ml} .) \\
P_{i} / P_{S}\end{array}$ & $\begin{array}{l}329 \\
303 \\
0.574 \\
0.582 \\
0.578 \\
3.71 \\
0.605\end{array}$ & $\begin{array}{l}25 \\
23 \\
0.044 \\
0.044 \\
0.044 \\
0.28 \\
0.046\end{array}$ & $\begin{array}{l}49 \\
42 \\
0.086 \\
0.081 \\
0.084 \\
0.54 \\
0.088\end{array}$ & $\begin{array}{l}54 \\
46 \\
0.094 \\
0.088 \\
0.091 \\
0.58 \\
0.095\end{array}$ & $\begin{array}{l}26 \\
22 \\
0.045 \\
0.042 \\
0.044 \\
0.28\end{array}$ & $\begin{array}{l}91 \\
83 \\
0.159 \\
0.159 \\
0.159 \\
1.02 \\
0.166\end{array}$ & 87 & 35 & $\begin{array}{l}609 \\
606\end{array}$ \\
\hline
\end{tabular}


TABLE IV

Results of the electrophoretic analysis of maternal plasmas and sera

The absolute concentrations, $P_{i}$, are in grams of protein per $100 \mathrm{ml}$ : of plasma or serum. The relative concentrations are on a serum basis, $P_{i} / P_{S}$, except for fibrinogen which is on the basis of plasma, $P_{\phi} / P_{P}$

\begin{tabular}{|c|c|c|c|c|c|c|c|c|c|c|c|c|c|}
\hline & \multicolumn{2}{|c|}{ Albumin } & \multicolumn{2}{|c|}{$\boldsymbol{\alpha}_{1}$} & \multicolumn{2}{|c|}{$\alpha z$} & \multicolumn{2}{|c|}{$\beta$} & \multicolumn{2}{|c|}{$\phi$} & \multicolumn{2}{|c|}{$\gamma$} & \multirow{2}{*}{$P_{S}$} \\
\hline & $P_{A} / P_{S}$ & $\boldsymbol{P}_{\boldsymbol{A}}$ & ${ }^{P_{\alpha \alpha_{1}}} / P_{S}$ & $P_{\alpha_{1}}$ & $P_{\alpha_{\varepsilon}} / P_{S}$ & $P_{\alpha z}$ & $\boldsymbol{P}_{\boldsymbol{\beta}} / \boldsymbol{P}_{S}$ & $P^{\beta}$ & $\boldsymbol{P}_{\phi} / \boldsymbol{P}_{\boldsymbol{P}}$ & $P_{\phi}$ & $\boldsymbol{P}_{\gamma} / P_{S}$ & $\boldsymbol{P}_{\boldsymbol{\gamma}}$ & \\
\hline $\begin{array}{c}1 \\
2 \\
3 \\
4 \\
5 \\
6 \\
7 \\
\text { I } \\
\text { II } \\
\text { III } \\
\mathrm{V}^{*}\end{array}$ & $\begin{array}{l}0.473 \\
0.545 \\
0.487 \\
0.517 \\
0.500 \\
0.478 \\
0.499 \\
0.494 \\
0.478 \\
0.507 \\
0.482\end{array}$ & $\begin{array}{l}3.49 \\
3.72 \\
3.23 \\
3.79 \\
3.21 \\
3.23 \\
3.11 \\
3.87 \\
3.66 \\
3.98 \\
3.86\end{array}$ & $\begin{array}{l}0.069 \\
0.068 \\
0.065 \\
0.075 \\
0.068 \\
0.077 \\
0.069 \\
0.058 \\
0.064 \\
0.056 \\
0.059\end{array}$ & $\begin{array}{l}0.51 \\
0.46 \\
0.43 \\
0.55 \\
0.44 \\
0.52 \\
0.43 \\
0.45 \\
0.49 \\
0.44 \\
0.47\end{array}$ & $\begin{array}{l}0.111 \\
0.130 \\
0.091 \\
0.131 \\
0.138 \\
0.112 \\
0.128 \\
0.114 \\
0.086 \\
0.083 \\
0.104\end{array}$ & $\begin{array}{l}0.82 \\
0.89 \\
0.60 \\
0.96 \\
0.89 \\
0.75 \\
0.80 \\
0.89 \\
0.66 \\
0.65 \\
0.83\end{array}$ & $\begin{array}{l}0.239 \\
0.198 \\
0.275 \\
0.189 \\
0.218 \\
0.220 \\
0.220 \\
0.188 \\
0.253 \\
0.254 \\
0.235\end{array}$ & $\begin{array}{l}1.76 \\
1.35 \\
1.82 \\
1.38 \\
1.40 \\
1.48 \\
1.37 \\
1.47 \\
1.94 \\
2.00 \\
1.88\end{array}$ & $\begin{array}{l}0.075 \\
0.087 \\
0.073 \\
0.051 \\
0.044 \\
0.067 \\
0.050\end{array}$ & $\begin{array}{l}0.60 \\
0.65 \\
0.52 \\
0.39 \\
0.30 \\
0.49 \\
0.33\end{array}$ & $\begin{array}{l}0.107 \\
0.059 \\
0.081 \\
0.088 \\
0.075 \\
0.114 \\
0.084 \\
0.145 \\
0.119 \\
0.100 \\
0.121\end{array}$ & $\begin{array}{l}0.79 \\
0.40 \\
0.54 \\
0.65 \\
0.48 \\
0.77 \\
0.52 \\
1.14 \\
0.91 \\
0.79 \\
0.97\end{array}$ & $\begin{array}{l}7.37 \\
6.82 \\
6.63 \\
7.33 \\
6.42 \\
6.75 \\
6.23 \\
7.83 \\
7.65 \\
7.85 \\
8.01\end{array}$ \\
\hline $\begin{array}{l}\text { Mean } \\
\text { S.D. }\end{array}$ & $\begin{array}{l}0.496 \\
0.021\end{array}$ & $\begin{array}{l}3.56 \\
0.31\end{array}$ & $\begin{array}{l}0.066 \\
0.007\end{array}$ & $\begin{array}{l}0.47 \\
0.04\end{array}$ & $\begin{array}{l}0.112 \\
0.019\end{array}$ & $\begin{array}{l}0.79 \\
0.12\end{array}$ & $\begin{array}{l}0.226 \\
0.028\end{array}$ & $\begin{array}{l}1.62 \\
0.26\end{array}$ & $\begin{array}{l}0.064 \\
0.016\end{array}$ & $\begin{array}{l}0.47 \\
0.13\end{array}$ & $\begin{array}{l}0.099 \\
0.025\end{array}$ & $\begin{array}{l}0.72 \\
0.23\end{array}$ & $\begin{array}{l}7.17 \\
0.63\end{array}$ \\
\hline
\end{tabular}

* Corresponding fetal sample lost.

fibrinogen. The average values are given in the next to the last line in each table. The standard deviations, S.D., given in the last line, were computed from the relation

$$
\text { S.D. }=\sqrt{\sum_{1}^{n}(V-V)^{2} /(n-1)}
$$

in which $\bar{V}$ is the mean of the $n$ individual values, $V$. Except for fibrinogen, there appears to be no systematic difference between serum and plasma in either the actual or the relative concentrations of the fetal components. This also appears to be true for the relative concentrations of the maternal components. The absolute concentrations of the maternal plasma components tend, on the other hand, to be below the corresponding maternal serum values. This may be accidental or it may be that we have underestimated the diluting effect of our anticoagulant. A small increase in the value of the maternal cell volume used in the computation of this effect would eliminate this discrepancy and also reduce our

TABLE V

Results of the electrophoretic analysis of fetal plasmas and sera

The absolute concentrations, $P_{i}$, are in grams of protein per $100 \mathrm{ml}$. of plasma or serum. The relative concentrations are on a serum basis, $P_{i} / P_{s}$, except for fibrinogen which is on the basis of plasma, $P_{\phi} / P_{P}$.

\begin{tabular}{|c|c|c|c|c|c|c|c|c|c|c|c|c|c|}
\hline & \multicolumn{2}{|c|}{ Albumin } & \multicolumn{2}{|c|}{$\infty$} & \multicolumn{2}{|c|}{$\alpha$} & \multicolumn{2}{|c|}{$\boldsymbol{\beta}$} & \multicolumn{2}{|c|}{$\phi$} & \multicolumn{2}{|c|}{$\gamma$} & \multirow{2}{*}{$P_{S}$} \\
\hline & $P_{A} / P_{S}$ & $\boldsymbol{P}_{\boldsymbol{A}}$ & $\boldsymbol{P}_{\boldsymbol{\alpha}_{1}} / \boldsymbol{P}_{S}$ & $P_{\alpha_{1}}$ & $P_{\alpha_{g}} / P_{S}$ & $P_{\boldsymbol{\alpha z}}$ & $\boldsymbol{P}_{\beta} / P_{S}$ & $P_{\beta}$ & $\boldsymbol{P}_{\boldsymbol{\phi}} / \boldsymbol{P}_{\boldsymbol{P}}$ & $\boldsymbol{P}_{\phi}$ & $\boldsymbol{P}_{\gamma} / P_{S}$ & $\boldsymbol{P}_{\boldsymbol{\gamma}}$ & \\
\hline $\begin{array}{c}1 \\
2 \\
3 \\
4 \\
5 \\
6 \\
7 \\
\text { I } \\
\text { II } \\
\text { III } \\
\text { IV* }\end{array}$ & $\begin{array}{l}0.641 \\
0.648 \\
0.614 \\
0.614 \\
0.637 \\
0.628 \\
0.605 \\
0.594 \\
0.632 \\
0.598 \\
0.600\end{array}$ & $\begin{array}{l}3.99 \\
4.16 \\
3.45 \\
3.87 \\
3.69 \\
3.75 \\
3.71 \\
3.48 \\
4.45 \\
3.69 \\
3.76\end{array}$ & $\begin{array}{l}0.037 \\
0.042 \\
0.042 \\
0.045 \\
0.069 \\
0.049 \\
0.046 \\
0.049 \\
0.043 \\
0.039 \\
0.051\end{array}$ & $\begin{array}{l}0.23 \\
0.27 \\
0.24 \\
0.29 \\
0.40 \\
0.30 \\
0.28 \\
0.29 \\
0.30 \\
0.24 \\
0.32\end{array}$ & $\begin{array}{l}0.091 \\
0.075 \\
0.083 \\
0.077 \\
0.089 \\
0.072 \\
0.088 \\
0.073 \\
0.078 \\
0.079 \\
0.077\end{array}$ & $\begin{array}{l}0.56 \\
0.48 \\
0.47 \\
0.48 \\
0.52 \\
0.43 \\
0.54 \\
0.43 \\
0.55 \\
0.49 \\
0.48\end{array}$ & $\begin{array}{l}0.093 \\
0.103 \\
0.115 \\
0.087 \\
0.093 \\
0.088 \\
0.095 \\
0.092 \\
0.103 \\
0.102 \\
0.102\end{array}$ & $\begin{array}{l}0.58 \\
0.66 \\
0.65 \\
0.55 \\
0.54 \\
0.53 \\
0.58 \\
0.54 \\
0.73 \\
0.63 \\
0.64\end{array}$ & $\begin{array}{l}0.063 \\
0.068 \\
0.055 \\
0.050 \\
0.045 \\
0.049 \\
0.044\end{array}$ & $\begin{array}{l}0.42 \\
0.47 \\
0.33 \\
0.33 \\
0.27 \\
0.31 \\
0.28\end{array}$ & $\begin{array}{l}0.138 \\
0.134 \\
0.147 \\
0.178 \\
0.113 \\
0.165 \\
0.166 \\
0.191 \\
0.143 \\
0.183 \\
0.170\end{array}$ & $\begin{array}{l}0.86 \\
0.86 \\
0.83 \\
1.12 \\
0.66 \\
0.99 \\
1.02 \\
1.12 \\
1.02 \\
1.13 \\
1.07\end{array}$ & $\begin{array}{l}6.22 \\
6.41 \\
5.63 \\
6.30 \\
5.80 \\
5.98 \\
6.14 \\
5.85 \\
7.05 \\
6.30 \\
6.27\end{array}$ \\
\hline $\begin{array}{l}\text { Mean } \\
\text { S.D. }\end{array}$ & $\begin{array}{l}0.619 \\
0.019\end{array}$ & $\begin{array}{l}3.82 \\
0.29\end{array}$ & $\begin{array}{l}0.047 \\
0.008\end{array}$ & $\begin{array}{l}0.29 \\
0.05\end{array}$ & $\begin{array}{l}0.080 \\
0.006\end{array}$ & $\begin{array}{l}0.49 \\
0.04\end{array}$ & $\begin{array}{l}0.097 \\
0.008\end{array}$ & $\begin{array}{l}0.60 \\
0.06\end{array}$ & $\begin{array}{l}0.053 \\
0.008\end{array}$ & $\begin{array}{l}0.34 \\
0.07\end{array}$ & $\begin{array}{l}0.157 \\
0.024\end{array}$ & $\begin{array}{l}0.97 \\
0.15\end{array}$ & $\begin{array}{l}6.18 \\
0.38\end{array}$ \\
\hline
\end{tabular}

* Corresponding maternal sample lost. 
TABLE VI

Comparison of the albumin-globulin ratio in maternal and fetal plasmas and sera

\begin{tabular}{l|c|c|c|c|c|c|c|c|c|c|c|c|c|c|}
\hline \multicolumn{1}{c|}{ Sample } & 1 & 2 & 3 & 4 & 5 & 6 & 7 & I & II & III & Mean & S.D. \\
\hline$P_{A} / P_{G}$ (maternal) & 0.90 & 1.20 & 0.95 & 1.07 & 1.00 & 0.92 & 0.99 & 0.98 & 0.92 & 1.03 & 1.00 & 0.09 \\
$P_{A} / P_{G}$ (fetal) & 1.79 & 1.83 & 1.58 & 1.58 & 1.75 & 1.68 & 1.53 & 1.47 & 1.72 & 1.48 & 1.64 & 0.13 \\
\hline
\end{tabular}

TABLE VII

Comparison of the ratio of $\gamma$-globulin to total serum globulin in maternal and fetal plasmas and sera

\begin{tabular}{l|c|c|c|c|c|c|c|c|c|c|c|c|c|c}
\hline \multicolumn{1}{c|}{ Sample } & 1 & 2 & 3 & 4 & 5 & 6 & 7 & I & II & III & Mean & S.D. \\
\hline$P_{\gamma / P_{G} \text { (maternal) }}$ (maternal & 0.203 & 0.130 & 0.158 & 0.183 & 0.151 & 0.218 & 0.168 & 0.287 & 0.228 & 0.203 & 0.193 & 0.045 \\
$P_{\gamma} / P_{G}$ (fetal) & 0.384 & 0.379 & 0.380 & 0.459 & 0.310 & 0.441 & 0.420 & 0.472 & 0.391 & 0.454 & 0.409 & 0.050 \\
\hline
\end{tabular}

standard deviations for the actual concentrations of the maternal components.

\section{Discussion}

Of especial interest in connection with infant immunity is the distribution of the maternal and fetal globulins. A comparison of the conventional albumin-globulin ratio, $P_{A} / P_{G},{ }^{2}$ with the ratio, $P_{\gamma} / P_{G}$, of $\gamma$ to total globulin serves to emphasize the differences between the two types of material. Values of these ratios are recorded in Tables VI and VII, respectively, for each of the 10 pairs of plasmas or sera. Without exception, the albumin-globulin ratio is higher for a fetal than for the corresponding maternal sample. This confirms the observations of previous workers that, relative to maternal serum, the fetal material is rich in albumin and poor in total globulin. The electrophoretic method yields the additional information that the concentration distribution of the individual globulins is quite different in the two types of material. Although poor in total globulin, the fetal samples are relatively rich in the presumably antibody-containing $\gamma$ globulin, the fetal values of $P_{\gamma} / P_{G}$, Table VII, being, without exception, significantly higher than the corresponding maternal values. This result is compatible with the comparatively

2 Although there is some evidence (15) that the solubility of the $\alpha_{1}$ component corresponds to that of an albumin, it has been classified here as a globulin. When this component was first reported (6), the author did not state explicitly that it was a globulin but the terminology he suggested implied that he considered it to belong in this class of proteins. This was the result of the observation that $\alpha_{1}$ was absent from a preparation of human serum albumin that still contained traces of $\alpha_{2}$ and $\beta$ globulin. high degree of immunity possessed by the newborn infant.

These relationships are illustrated graphically in Figure 3 in which tracings of Figures 1 and 2 have been superimposed, the maternal and fetal patterns being indicated by the full and dashed lines, respectively. We have also noted that in the electrolysis of a fetal sample it is always the $\gamma$ globulin peak that first separates from the initial boundary whereas with a maternal sample the first to separate is that due to $\beta$ globulin.

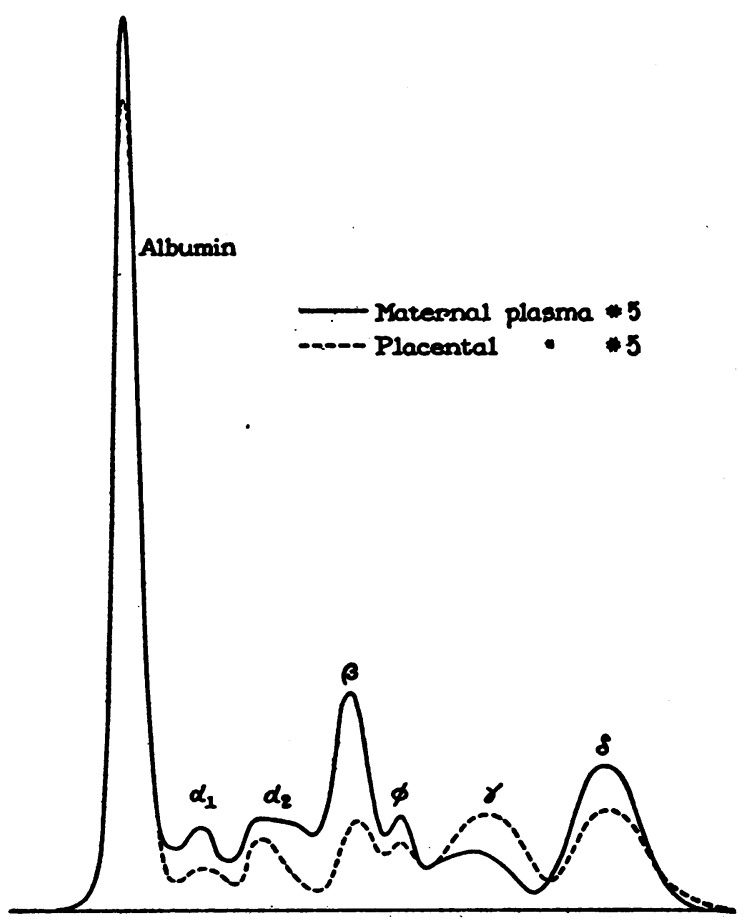

Fig. 3. Superimposed Tracings of the Patterns of FIGS. 1 AND 2 
Even the absolute concentration of a fetal $\gamma$ globulin tends to be somewhat above that of the corresponding maternal sample, in spite of the relatively low concentration of total globulin in the fetal material. It will be noted, however, that the marked differences between the fetal and maternal values of $P_{\gamma} / P_{G}$, Table VII, are due, in part, to the relatively high concentrations of the maternal $\alpha_{1}, \alpha_{2}$, and $\beta$ globulins. The following comparison of our results with those for normal adults recently reported (8) is of interest in this connection.

The experimental procedure employed in that report was similar to that used in this research except that the relative concentrations were computed only from the pattern areas, the concentration of total protein being obtained from nitrogen determinations. These relative concentrations are, therefore, comparable with ours and are given, after conversion to a serum basis, in Table VIII, which also includes the fetal and

TABLE VIII

The relative concentrations of the serum protein components of normal, fetal, and maternal plasmas and sera

\begin{tabular}{l|c|c|c|c|c}
\hline \hline & $P_{A} / P_{S}$ & $P_{\alpha 1} / P_{S}$ & $P_{\alpha z} / P_{S}$ & $P_{\beta} / P_{S}$ & $P_{\gamma} / P_{S}$ \\
\hline Normal & 0.633 & 0.049 & 0.075 & 0.127 & 0.116 \\
Fetal & 0.619 & 0.047 & 0.080 & 0.097 & 0.157 \\
Maternal & 0.496 & 0.066 & 0.112 & 0.226 & 0.099 \\
\hline
\end{tabular}

maternal values for comparison. It is evident from this table that the distribution of the fetal proteins is much more nearly normal than that of the maternal proteins. Although the relative concentration of fetal $\gamma$ globulin tends to be above normal, whereas that of $\beta$ globulin is below normal, the differences are not great. The relative concentrations of the maternal $\alpha_{1}, \alpha_{2}$, and $\beta$ globulins, especially the latter, are, on the other hand, considerably above the normal values. It has already been noted (16) that the values published in connection with the study of buffer solvents (6) were abnormal. This discrepancy is, of course, explained by the fact that the material used in that study was a maternal plasma.

The absolute concentrations of the proteins in normal, fetal, and maternal plasmas are compared in Table IX. In using this table, allowance should be made for the fact that the normal
TABLE IX

The concentrations, in grams per $100 \mathrm{ml}$., of the protein components of normal, fetal, and maternal plasmas and sera

\begin{tabular}{|c|c|c|c|c|c|c|c|}
\hline & $\boldsymbol{P}_{\boldsymbol{A}}$ & $P_{\alpha \mathbf{a n}}$ & $P_{\alpha_{s}}$ & $\boldsymbol{P}_{\boldsymbol{\beta}}$ & $P_{\phi}$ & $\boldsymbol{P}_{\boldsymbol{\gamma}}$ & $\boldsymbol{P}_{\boldsymbol{S}}$ \\
\hline $\begin{array}{l}\text { Normal* } \\
\text { Fetal } \\
\text { Maternal }\end{array}$ & $\begin{array}{l}4.04 \\
3.82 \\
3.56\end{array}$ & $\begin{array}{l}0.31 \\
0.29 \\
0.47\end{array}$ & $\begin{array}{l}0.48 \\
0.49 \\
0.79\end{array}$ & $\begin{array}{l}0.81 \\
0.60 \\
1.62\end{array}$ & $\begin{array}{l}0.34 \\
0.34 \\
0.47\end{array}$ & $\begin{array}{l}0.74 \\
0.97 \\
0.72\end{array}$ & $\begin{array}{l}6.38 \\
6.18 \\
7.17\end{array}$ \\
\hline
\end{tabular}

* From nitrogen determinations-fetal and maternal values obtained refractometrically.

values, which were obtained with the aid of nitrogen determinations, are probably a little lower than the refractometrically measured maternal and fetal values.

It has been shown (17) that a large proportion of the serum lipids is carried by the $\alpha_{2}$ and $\beta$ globulins. These components occur in increasing amounts in the fetal, normal, and maternal samples and thus parallel, roughly, the lipid content of these materials. This is illustrated by the data of Table $\mathrm{X}$, the total lipid and

TABLE $\mathbf{X}$

The concentrations, in grams per $100 \mathrm{ml}$. of solution, of $\alpha_{2}+\beta$ globulin and of total lipid and cholesterol in fetal, normal, and maternal plasmas and sera

\begin{tabular}{l|l|l|l}
\hline \hline & Fetal & Normal & Maternal \\
\hline$\alpha_{2}+\beta$ globulin & 1.09 & 1.29 & 2.41 \\
Total lipid & 0.198 & 0.617 & 0.900 \\
Total cholesterol & 0.034 & 0.181 & 0.205 \\
\hline
\end{tabular}

cholesterol values of that table being taken from other reports $(18,19)$ and the combined concentrations of $\alpha_{2}$ and $\beta$ globulin being computed from the data of Table IX.

\section{SUMMARY}

Ten pairs of maternal and fetal plasmas, or sera, taken at the time of child-birth have been analyzed electrophoretically. The concentrations of the electrophoretically separable fetal proteins have been compared with those of the corresponding maternal components and also with the values for normal adult plasma recently reported (8). The relative concentrations of the maternal components exhibit greater deviations from the normal values than do those of the fetal samples, the concentration of maternal $\beta$ globulin being significantly above normal. Both the absolute and the relative concentrations of 
fetal $\boldsymbol{\gamma}$ globulin are higher than either the normal or maternal values. Since the $\gamma$ component includes many of the antibody globulins this result is consistent with other evidence as to the natural immunity of the new-born infant.

There are several sources of experimental error in the measurement of absolute protein concentrations with the aid of the electrophoretic method that do not enter into the determination of relative values. A discussion of these errors is also included and procedures are suggested which, it is hoped, will aid in their elimination.

It is a pleasure to acknowledge our indebtedness to Dr. Vincent P. Dole of the Hospital of The Rockefeller Institute for the opportunity of discussing with him many of the problems associated with this investigation and to Dr. D. A. MacInnes of the Laboratories of The Rockefeller Institute for his suggestions in the preparation of this report.

\section{BIBLIOGRAPHY}

1. Plass, E. D., and Matthew, C. W., Placental transmission. IV. The protein fractions in fetal and maternal plasma. Am. J. Obst. and Gynec., 1926, $12,847$.

2. Rapoport, M., Rubin, M. I., and Chaffee, D., Fractionation of the serum and plasma proteins by salt precipitation in infants and children. 1. The changes with maturity and age. 2. The changes in glomerulonephritis. 3. The changes in nephrosis. J. Clin. Invest., 1943, 22, 487.

3. Trevorrow, V., Kaser, M., Patterson, J. P., and Hill, R. M., Plasma albumin, globulin and fibrinogen in healthy individuals from birth to adulthood. J. Lab. and Clin. Med., 1942, 27, 471.

4. McKhann, C. F., and Kapnick, I., Immunity and susceptibility to disease in early infancy. A critical review. J. Pediat., 1938, 13, 907.

5. Tiselius, A., A new apparatus for electrophoretic analysis of colloidal mixtures. Trans. Faraday Soc., 1937, 33, 524.

6. Longsworth, L. G., Recent advances in the study of proteins by electrophoresis. Chem. Rev., 1942, 30, 323.

7. Tiselius, A., and Käbat, E. A., An electrophoretic study of immune sera and purified antibody preparations. J. Exper. Med., 1939, 69, 119.

8. Dole, V. P., The electrophoretic patterns of normal plasma. J. Clin. Invest., 1944, 23, 708.

9. Curtis, R. M., and Worthington, R. W., Jr., Placental blood plasma. Am. J. Obst. and Gynec., 1941, 42, 428.

10. Treffers, H. P., and Moore, D. H., The use of infra-red film for electrophoretic and ultracentrifugal analyses. Science, 1941, 93, 240.

11. Longsworth, L. G., The concentration distribution in two-salt moving boundaries. J. Am. Chem. Soc., 1944, 66, 449.

12. Darling, R. C., Smith, C. A., Asmussen, E., and Cohen, F. M., Some properties of human fetal and maternal blood. J. Clin. Invest., 1941, 20, 739.

13. Heller, V. G., and Paul, H., Changes in cell volume produced by varying concentrations of different anticoagulants. J. Lab. and Clin. Med., 1934, 19, 777.

14. Adair, G. S., and Robinson, M. E., The specific refraction increments of serum-albumin and serumglobulin. Biochem. J., 1930, 24, 993.

15. Blackman, S. S., Jr., and Davis, B. D., Electrophoretic and chemical analysis of protein in nephritic urine. J. Clin. Invest:, 1943, 22, 545.

16. Kekwick, R. A., and McFarlane, A. S., The chemistry of the proteins and amino acids. II. Ann. Rev. Biochem., 1943, 12, 93.

17. Blix, G., Tiselius, A., and Svensson, H., Lipids and polysaccharides in electrophoretically separated blood serum proteins. J. Biol. Chem., 1941, 137, 485.

18. Boyd, E. M., The lipemia of pregnancy. J. Clin. Invest., 1934, 13, 347.

19. Boyd, E. M., Lipid composition of blood in new-born infants. Am. J. Dis. Child., 1936, 52, 1319. 